\title{
The Physical, Chemical and Antioxidant Properties of the Leafs of Chaerophyllum byzantinum Boiss. Plants
}

\author{
Ilkay Koca, Belkis Tekguler, Volkan Arif Yilmaz* \\ Department of Food Engineering, Faculty of Engineering, Ondokuz Mayıs University Samsun, TURKEY.
}

\begin{abstract}
Objective: Chaerophyllum byzantinum Boiss. is a plant which is popularly consumed in the Black Sea Region/Turkey. In spring, the leafs of the plant are mainly used for soup making. This study was carried out in order to determine the physical, chemical and antioxidant properties of the leafs of the plants consumed by people. Material and Methods: The plants were obtained from 8 different locations in Samsun/Turkey. The color, $\mathrm{pH}$, dry matter, ash, crude protein, cellulose, crude fat, total phenolics and antioxidant activity (FRAP and DPPH) analysis were performed to the samples. Results: The results of analysis performed to the leafs of the plants were found as; Lightness $(L) 36.99 \pm 2.84$, greenness (a) $-12.56 \pm 1.60$, yellowness $(b) 15.79 \pm 2.14$, dry matter $16.43 \pm 0.41 \%$, ash $2.03 \pm 0.20 \%$, crude cellulose $1.95 \pm 0.23 \%$, crude protein $4.36 \pm 0.31 \%$, crude fat $0.57 \pm 0.16 \%$, total phenolics $2890.15 \pm 945.33 \mathrm{mg} / \mathrm{kg}$, FRAP $7406.68 \pm 4728.03 \mu \mathrm{mol} / \mathrm{g}$ and $\mathrm{EC}_{50}$ value $1.00 \pm 0.61 \mathrm{mg} / \mathrm{ml}$, respectively. Conclusion: It has been observed that the plant, which is a good dietary fiber and mineral source, also has high phenolic compounds and antioxidant activity. However, the changes in phenolic compounds and antioxidant activity were found to be quite wide. Growing conditions seem to have a significant effect on the bioactive compounds than the physical and chemical properties.
\end{abstract}

Key words: Chaerophyllum byzantinum Boiss, Edible plant, Antioxidant, Phenolics, Chemical, Color.

\section{INTRODUCTION}

Turkey has a great deal of plant genetic resources because of its geographical structure and different ecological conditions. Turkey is one of the most important countries in the world in terms of plant species richness and endemic plants. Turkish flora contains 10,754 plant species, 3,708 of which are endemic (Guner et al. 2000). Many plant species are collected from their natural habitats by indigenous people and are traditionally used for several purposes such as natural food, tea, herbal medicine and animal fodder in Turkey (Ozhatay et al. 1997). Among plant genetic resources, wild edible plants have been widely used as food sources by people since ancient times Turkey has a great deal of plant genetic resources because of its geographical structure and different ecological conditions. Turkey is one of the most important countries in the world in terms of plant species richness and endemic plants.

Turkish flora contains 10,754 plant species, 3,708 of which are endemic (Guner et al. 2000). Many plant species are collected from their natural habitats by indigenous people and are traditionally used for several purposes such as natural food, tea, herbal medicine and animal fodder in Turkey (Ozhatay et al. 1997). Among plant genetic resources, wild edible plants have been widely used as food sources by people since ancient times Because of its geographical structure and different ecological conditions, Turkey has important plant genetic resources. Interms of plant species richness and endemic plants, Turkey is one of the most important countries in the world. ${ }^{1}$ One of these endemic plants is the Chaerophyllum genus. It is represented by 15 species, four of them are
Submission Date: 30-08-2017; Revision Date: 17-11-2017; Accepted Date: 23-11-2017

DOI: 10.5530/ijper.52.4s.87 Correspondence: Volkan Arif Yilmaz, Department of Food Engineering, Faculty of Engineering, Ondokuz Mayıs University Samsun, TURKEY. Phone: +903623121919-1514 E-mail: volkan.yilmaz@omu. edu.tr

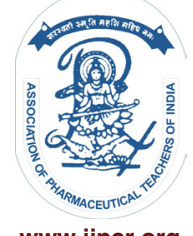

www.ijper.org 
endemic in Turkey. ${ }^{2}$ Chaerophyllum genus belongs to Apiaceae family, comprised of about 110 species widely distributed in temperate and sub temperate zones of Asia, Europe and Africa. ${ }^{3}$ Chaerophyllum byzantinum Boiss. is generally distributed over north and northwest of Turkey. It also grows in the southeast Balkans and it was brought to Germany and consumed by Turkish immigrants as vegetables. ${ }^{2}$ The leafs of the plant are mainly used for traditional soup making especially in Northern part of Turkey. ${ }^{4}$ This study was carried out to determine the general composition and antioxidant properties of this wild plant consumed as vegetables by people.

\section{MATERIALS AND METHODS MATERIALS}

Fresh leaves of $C$. byzantinum Boiss. were collected from Samsun (40 59' 22.5924” N, 36³7' 50.9844” E) at an altitude of $78 \mathrm{~m}$. The plants were identified by Department of Botany, Ondokuz Mayis University, Samsun, Turkey.

\section{METHODS}

\section{Proximate analysis}

Color measurement was made with a Minolta CR 400 (Japan) colorimeter; color, L (100, lightness, 0, darkness), a (+, redness, -, greenness), b (+, yellowness, -, blueness). Dry matter analysis was carried out by drying to a constant weight at $105^{\circ} \mathrm{C}$. The ash analysis was made by burning to $550^{\circ} \mathrm{C}$ until the white ash was obtained in the ash furnace. Protein analysis was obtained by multiplying the total nitrogen amount obtained by the Kjeldahl method by a factor of 6.25. Crude fat analysis was performed by soxhelet extraction with diethyl ether for $8 \mathrm{~h}$. The Weende method was used for the determination of crude cellulose. For this purpose, oil free samples were boiled with $1.25 \% \mathrm{H} 2 \mathrm{SO} 4$ and then $1.25 \% \mathrm{NaOH}$, washed with alcohol, dried at $105{ }^{\circ} \mathrm{C}$ and weighted. ${ }^{5}$

\section{Total phenolics and antioxidant activity analysis}

The samples were extracted with $80 \%$ methyl alcohol in the refrigerator for $12 \mathrm{~h}$ and then filtered to remove the clarified portion. The total phenolic content (TPC) was determined by measuring the phenolic compounds with a Folin-Ciocalteu solution in alkaline medium. ${ }^{6}$ For FRAP analysis; extracted samples were diluted appropriately and diluted in $300 \mathrm{mM}$ acetate buffer: $20 \mathrm{mM}$ $\mathrm{FeCl}_{3}: 10 \mathrm{mM}$ 2,4,6-tripyridyl-s-triazine (TPTZ) solution $(40 \mathrm{mM} \mathrm{HCl})$ and the absorbance at $593 \mathrm{~nm}$ in the spectrophotometer was determined. ${ }^{7}$ Calibration curves were drawn with the aid of $\mathrm{FeSO}_{4}$-prepared solutions and the antioxidant activity was calculated. The free radical scavenging effect was determined by DPPH (2,2-diphenyl-1-picrylhydrazyl) method. $50 \mu \mathrm{L}$ of the extract was taken and incubated with $1 \mathrm{~mL}$ of DPPH solution $(100 \mu \mathrm{M})$. The absorbance was determined by reading at $517 \mathrm{~nm}$. A control sample was also prepared and the $\%$ inhibition of DPPH was calculated by determining the absorbance. The results are expressed in $\mathrm{EC}_{50}{ }^{8}$

\section{RESULTS AND DISCUSSION}

Some physical and chemical properties of C. byzantium Boiss. plant leafs were given in Table 1 and the antioxidant properties of the leafs were given in Table 2.

Sekeroglu et al. ${ }^{9}$ determined the composition of some plants naturally grown in the Black Sea region (Ornithogalum umbellatum, Similax excelsa, Trachystemon orientalis, Aegopodium podograria, Amaranthus retroflexus and Urtica diocia). Dry matter (7.5-18.5\%), ash (4.1$22.8 \%)$, crude fat $(0.1-2.0 \%)$ and crude protein (1.3$4.3 \%$ ) content of these plants were reported by

\begin{tabular}{|c|c|c|c|c|c|c|c|c|}
\hline \multicolumn{7}{|c|}{ Table 1: Some physical and chemical properties of C. byzantium Boiss. leafs. } \\
\hline Sample & $\begin{array}{c}\text { DM } \\
(\%)\end{array}$ & $\begin{array}{c}\text { Ash } \\
(\%)\end{array}$ & $\begin{array}{c}\text { Crude } \\
\text { cellulose } \\
(\%)\end{array}$ & $\begin{array}{c}\text { Crude } \\
\text { protein } \\
(\%)\end{array}$ & $\begin{array}{c}\text { Crude fat } \\
(\%)\end{array}$ & L & a & b \\
\hline 1 & 16.38 & 1.88 & 2.27 & 4.27 & 0.67 & 41.97 & -15.34 & 18.53 \\
\hline 2 & 16.51 & 2.01 & 1.99 & 4.12 & 0.54 & 36.23 & -11.80 & 17.53 \\
\hline 3 & 16.16 & 1.98 & 1.91 & 4.71 & 0.74 & 35.33 & -12.21 & 14.43 \\
\hline 4 & 15.93 & 1.91 & 1.94 & 4.31 & 0.39 & 40.18 & -14.45 & 18.08 \\
\hline 5 & 16.45 & 2.02 & 1.49 & 4.13 & 0.38 & 38.22 & -12.62 & 16.53 \\
\hline 6 & 16.65 & 2.14 & 1.95 & 4.84 & 0.49 & 35.21 & -12.09 & 14.42 \\
\hline 7 & 16.11 & 1.86 & 2.15 & 4.54 & 0.82 & 34.37 & -11.57 & 13.83 \\
\hline 8 & 17.27 & 2.47 & 1.91 & 3.94 & 0.50 & 34.39 & -10.37 & 12.97 \\
\hline Mean & $16.43 \pm 0.39$ & $2.03 \pm 0.19$ & $1.95 \pm 0.21$ & $4.36 \pm 0.29$ & $0.57 \pm 0.15$ & $36.99 \pm 2.66$ & $-12.56 \pm 1.50$ & $15.79 \pm 2.00$ \\
\hline
\end{tabular}




\begin{tabular}{|c|c|c|c|}
\hline Sample & $\begin{array}{c}\text { TPC } \\
(\mathrm{mg} / \mathrm{kg})\end{array}$ & $\begin{array}{c}\text { FRAP } \\
(\mu \mathrm{mol} / \mathrm{g})\end{array}$ & $\begin{array}{c}E_{50} \\
(\mathrm{mg} / \mathrm{ml})\end{array}$ \\
\hline 1 & 2363.75 & 3923.44 & 1.28 \\
\hline 2 & 3076.25 & 8735.94 & 0.30 \\
\hline 3 & 4401.25 & 12548.44 & 1.37 \\
\hline 4 & 3378.12 & 3163.12 & 0.28 \\
\hline 5 & 3221.87 & 3388.12 & 1.24 \\
\hline 6 & 3378.12 & 2225.62 & 2.07 \\
\hline 7 & 1613.44 & 13126.56 & 0.69 \\
\hline 8 & 1688.44 & 12142.19 & 0.77 \\
\hline Mean & $2890.2 \pm 884.3$ & $7406.7 \pm 4422.7$ & $1.00 \pm 0.57$ \\
\hline
\end{tabular}

researchers. The dry matter and fat results of researchers are close to our findings. Bouba et al..$^{10}$ evaluated composition of 20 edible wild plants used as spices in Cameroon. They found that the plant's ash contents were between 7.7 and $10.5 \%$ on dry weight (DW). When we evaluate the amount of ash in our samples on DW, it is seen that our study is a little higher than these results. Tunçturk et al. ${ }^{11}$ determined the composition of three different plant species (Capsella bursa-pastoris (L.) Medik, Gundelia tournefortii L. var. tournefortii and Arum elongatum Steven subsp. detruncatum) which grow wild in Anatolia. The researchers found that these crops contained 14.36$18.72 \%$ of dry matter, $6.67-15.33 \%$ of ash, $8.47-21.00 \%$ of crude protein and $19.38-36.44 \%$ of crude fiber. Similarly, when we evaluate the results of our samples on DW, they found in the same range. Kibar and Temel ${ }^{1}$ evaulated composition of four wild edible plants (Beta corolliflora, Primula auriculata, Bellevalia forniculata and Caltha polypetala) growing in Turkey. They determined the moisture (79.73-86.10\%) and ash (7.33-17.12\%) content of the plants. It appears that the ash contents of this edible plants arein range with our samples on DW. As seen in Table 2, C. byzantinum Boiss plant's TPC, FRAP and $\mathrm{EC}_{50}$ values were determined in a wide range. Özen $^{12}$ investigated the bioactive compounds and antioxidant activity of 11 edible wild plants including C. byzantinum in Turkey. It was reported that TPC of C. byzantinum were determined $23.2 \mathrm{mg} / \mathrm{g}$ in DW. This result are in parallel to our findings on DW. Seal ${ }^{13}$ determined the TPC and $\mathrm{EC}_{50}$ values of some wild plants in India. It was given that TPC of the leaves ranged from 17.32 to $30.98 \mathrm{mg} / \mathrm{g} ; \mathrm{EC}_{50}$ value was found between 0.24-3.33 mg/ml on DW. Taskin and Bitis ${ }^{14}$ evaluated the total phenolic contents and antioxidant activity of ethanol extracts from eight wild edible plants in Turkey. They found that the TPC in extracts varied between 7.00 and $68.67 \mathrm{mg} / \mathrm{g}$. According to the results of these plants, phenolic content and antioxidant power of our samples were found in the same range. The results of various researchers on several plants are similar to our findings but show a wide range. This is probably due to the variety of species as well as the differences in soil, climate and the part of plant analyzed.

\section{CONCLUSION}

In the present study, the antioxidant activities and total phenolic contents of $C$. byzantinum Boiss. plants growing in Turkey were evaluated. It is seen that the bioactive components of this wild plant consumed by the public as vegetable and spice are similar to other wild plants in the literature and it has the potential of contributing to the health and nutritional needs of their consumers.

\section{ACKNOWLEDGEMENT}

Authors wanted to thank Ondokuz Mayis University, Samsun, Turkey for support.

\section{CONFLICT OF INTEREST}

Authors declare no conflict of interest.

\section{ABBREVIATIONS}

-a: Greenness; +b: Yellowness; DM: Dry matter; DPPH: 1,1-diphenyl-2-picrylhydrazyl; DW: Dry weight; EC $_{50}$ : Half-maximal effective concentration; FRAP: Ferric reducing ability of plasma; L: Lightness; TPC: Total phenolics content; TPTZ: 2,4,6-tripyridyls-triazine.

\section{REFERENCES}

1. Kibar B, Temel S. Evaluation of mineral composition of some wild edible plants growing in the Eastern Anatolia Region grasslands of Turkey and consumed as vegetable. J Food Proc and Pres. 2016;40(1):56-66.

2. Kürkçüoglu M, Baser KHC, Iscan G, Malyer H, Kaynak G. Composition and anticandidal activity of the essential oil of Chaerophyllum byzantinum Boiss. Flav Fragr J. 2006;21(1):115-7.

3. Joshi RK. Antimicrobial activity of leaf essential oil of Chaerophyllum villosum Wall. Ex DC. From Kumaun Himalayan of Uttrakhand. Ind Am J Pharm Res. 2013;3(2):1503-9.

4. Gladis T, Pistrick K. Chaerophyllum byzantinum Boiss. and Trachystemon orientalis (L.) G. Don-recently introduced from Turkish wild flora as new crop species among other interesting findings from immigrant gardens in Western Germany. Genet Resour Crop Evol. 2011;58(1):165-74.

5. AOAC. Official Methods of Analysis. Association of Official Analytical Chemists. 17th ed. USA. 2000.

6. Singleton VL, Rossi JA. Colorimetry of Total Phenolics with PhosphomolybdicPhosphotungstic Acid Reagents. Am J Enol Vitic. 1965;16(3):144-58.

7. Gao X, Björk L, Trajkovski V, Uggla M. Evaulation of antioxidant activities of rosehip ethanol extracts in different test systems. J Agric Food Chem. 2000;80(14):2021-7. 
ural S, Koca I. Physico-chemical and antioxidant properties of cornelian cherry fruits (Cornus mas L.) grown in Turkey. Sci Hortic. 2008;116(4):362-6.

9. Sekeroglu N, Ozkutlu F, Deveci M, Dede O, Yilmaz N. Evaluation of some wild plants aspect of their nutritional values used as vegetable in Eastern Black Sea Region of Turkey. Asian J Plant Sci. 2006;5(2):185-89.

10. Bouba AA, Njintang YN, Foyet HS, Scher J, Mbufong CMF. Proximate composition, minerals and vitamins contents of some wild plants used as spaces in Cameroun. Food Nutr Sci. 2012;3(4):423-32.
11. Tuncturk M, Eryigit T, Şekeroglu N, Ozgokce F. Chemical composition of some edible wild plants grown in Eastren Anatolia. Am J Essent Oils Nat Prod. 2015;2:31-4.

12. Özen T. Antioxidant activity of wild edible plants in the Black Sea Region of Turkey. Grasas Y Aceites. 2010;61(1):86-94

13. Seal T. Determination of nutritive value, mineral contents and antioxidant activity of some wild edible plants from Meghalaya State, India. Asian J Apl Sci. 2011;4(3):238-46.

14. Taskin T, Bitis L. In vitro antioxidant activity of eight wild edible plants in Bursa province of Turkey. Farmacia. 2016;64(5):706-11.
PICTORIAL ABSTRACT

\section{Chaerophyllum byzantinum Boiss.}

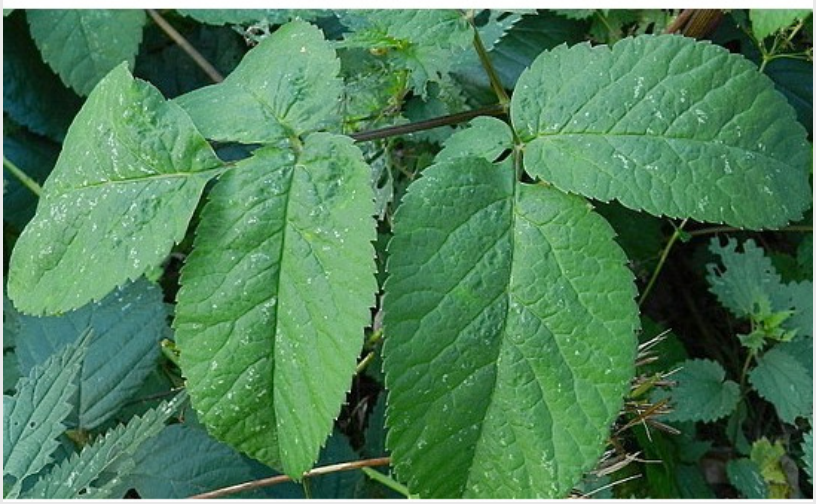

\section{SUMMARY}

- Chaerophyllum byzantinum Boiss. is generally distributed over the north of Turkey and the southeast Balkans. The leafs of the plant are mainly used for traditional soup making and as a spice in Turkey. It is seen that this wild plant has the potential of contributing to the health and nutritional needs of their consumers.

\section{About Authors}

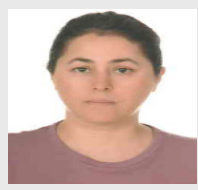

Dr. Koca: Is a member of Department of Food Engineering, Faculty of Engineering, Ondokuz Mayis University, Samsun, TURKEY. Functional and technological properties of edible wild plants is one of the research interest of her.

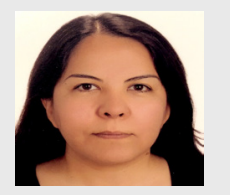

Dr. Tekguler: Is an Assist. Prof. Since 2006 in Department of Food Engineering, Faculty of Engineering, Ondokuz Mayis University, Samsun, TURKEY.

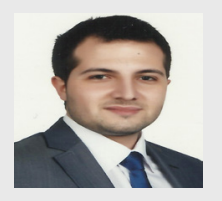

Dr. Yilmaz: Is working as Research Assistant since 2010 in Department of Food Engineering, Faculty of Engineering, Ondokuz Mayis University, Samsun, TURKEY.

Cite this article: Koca I, Tekguler B, Yilmaz VA. The Physical, Chemical and Antioxidant Properties of the Leafs of Chaerophyllum byzantinum boiss. Plants. Indian $\mathrm{J}$ of Pharmaceutical Education and Research. 2018;52(4S):S124-S127. 